\title{
Employability of Iranian Engineering graduates: Influential factors, consequences and strategies
}

\author{
Hamid Farhadi Rad ${ }^{1}$, Abdollah Parsa $^{1}$, Elahe Rajabi ${ }^{1}$ \\ Corresponding author: Hamid Farhadi Rad (h.farhadirad@scu.ac.ir) \\ ${ }^{1}$ Shahid Chamran University of Ahvaz
}

\begin{abstract}
University education is a significant factor in the socio-economic development of a nation and as such is expected to improve the employability capacity of the graduates. Achieving this goal, however, depends on various factors. The present study investigated the factors affecting the employability of engineering graduates of Iranian universities. To analyse this issue, a systematic grounded theory (GT) approach, drawing on in-depth interviews with academic and industry experts, was used. The participants were selected using a purposive strategy. The data analyses showed that employability is a context-oriented issue, and in addition to the university and its internal mechanisms, external factors are also involved. Based on the data, a model is presented and analysed to explain the employability of engineering graduates.
\end{abstract}

Keywords employability, engineering graduates, universityIndustry relations, skill training, grounded theory

\section{Introduction}

The employability of university graduates is an expectation of all stakeholders and is emphasised in national documents and government policies in Iran. Therefore, individuals and governments invest in universities as one of the basic mechanisms in creating and enhancing job opportunities for graduates. In Iran, evidence such as the unemployment rate of graduates and its increasing trend (Statistical Center of Iran, 2018), graduates' lack of practical skills, the large gap between their abilities and the market requirements (Entezari, 2016), and the poor link between the university, industry and the society (Sohrabi, Ebrahimi, \& Joukar, 2016), all show that higher education is facing serious challenges. According to the Statistical Center of Iran and based on the unemployment definition given by this center ${ }^{1}$, the unemployment rate of graduates of higher education comprised $37 \%$ of the whole rate of unemployment in 2017; this reached $40.5 \%$ in 2018 (Statistical Center of Iran, 2018). This is higher than the unemployment rate of graduates in South Korea (3.2\%), Denmark (6.3\%), Australia (7\%), Germany (8.5\%), and Turkey (9.3\%) (OEDC, 2018). Studies on the employment of graduates by Iranian researchers (e.g., Aghapour, Movahed, \& Alam Beigi, 2014; Memarian, 2011; Parand, Niroumand, Farajiarmaki, Alizadeh, \& Ahadieh, 2011) show that multiple factors, including

\footnotetext{
1 The definition of unemployment by the Statistical Centre of Iran is a person who incorporates all the three following conditions; having no job, seeking a job, and ready for doing a job. Therefore, those graduates who are doing a job related to their field of study are not counted as unemployed.
} 
the increased number of universities, outdated curricula of universities, and the severe incongruence between the disciplines and market needs, have contributed to this situation. Thus, the issue of graduates' employability is an important construct in higher education policymaking in Iran (Aghapour et al., 2014). Also, the elimination of barriers to unemployment for graduates has always been one of the main goals of governments in Iran (Khoshnevisan, Nasr, Neyestani, \& Sharif, 2016). Given the focus on the importance of graduates' employability in Iran, the question which remains is, have the universities contributed to this undesirable situation?

\section{Literature review}

Given that Engineering graduates, compared to other professions, have more impact on the national welfare structure, developing skills and using acquired knowledge is particularly significant in this field (Rahdari, Nasr, Nili, \& Turkladani, 2015). Accordingly, the Engineering Room has always been one of the requirements and priorities of higher education in Iran since the establishment of Dar ulFunun in 1982 (Frasatkhah, 2017). Iranian society expects engineers to be technically expert and socially responsible and innovative. The presence of individuals with high levels of expertise and social skills is essential to enable efficiency, entrepreneurship, and optimum enhancement of a context that is based on complicated technical and static systems. As such, quality instruction through the higher education sector is required to prepare future engineers (Yaghoubi \& Motahharenejad, 2011). However, the graduates of engineering faculties reflect a lack of correlation between society and workplace expectations (Feyz, 2010). According to studies by the National Academy of Engineering (NAE) (1995), a large number of students are graduated from the higher education institutions and universities, but in general, most of them neither meet the necessary skills needed to be active in the industry nor are they responsive to the current and future demands of this area (Aghapour et al., 2014).

Some of these inefficiencies are evident in other studies. For example, Gharba, Rahimi \& Dehbashi (2018) reported on the lack of relevance between the content of courses and the requirements of jobs, while Rahmani and Nazari (2003) revealed the gap between the training processes for engineering students and the skills and abilities required in the workplace. Similarly, other studies have shown that instruction is not in line with market and industry demands (Momeni Mahmoei, Shariatmadari, \& Naderi, 2008) and that graduates do not acquire adequate practical experience while studying (Barabadi, Mohammadi, \& Asadi, 2009). A study by Memarian (2011) revealed that the focus is on knowledge acquisition rather than on the skills and attitudes relevant to the working professional. Other research has shown that university training does not play any significant role in the students' employment in Iran (Nozari \& Karimi, 2017). The result of these reported deficiencies in the university system has been an increasing rate of unemployment of university graduates from four to 20\% from 1996 to 2016 (Mohseni-Cheraghlou, 2017). Within this context, the situation for engineering graduates is worse, with unemployment rates within the various fields of engineering of 41.4\% (Computer Sciences), 37.6\% (Environment Protection), 27.7\% (Construction), and 25.6\% (Industry and Processing) (Statistical Center of Iran, 2018). One the reasons for the high unemployment rate of engineering graduates, is the strong interest of students in this field of knowledge. Such a trend has led to an extensive rise in the number of universities and courses in engineering in Iran. According to the statistics presented by the Institute for Research and Planning in Higher Education (2017), the total number of students in Iran is approximately more than four million from among which $28.8 \%$ are students of engineering. According to the information in Table 1 , this number constitutes a high proportion in comparison to other countries ${ }^{2}$.

Many studies have investigated the reasons why students are attracted to engineering. Some of these reasons include financial issues (Motabari, 1999), finding a better job, achieving a more prestigious social status, pressure from family and friends (National Youth Organisation, 2001),

\footnotetext{
2 Reference: Higher Education Statistics, extracted from the Institute for Research and Planning in Higher education (Iran, 2017).
}

Farhadi Rad, H., Parsa, A., \& Rajabi, E. (2020). Employability of Iranian Engineering graduates: Influential factors, consequences and strategies Journal of Teaching and Learning for Graduate Employability, 11(1), 110-130. 
income (Enayati Novinfar, Darani, \& Karamdoust, 2013), direct interest, indirect interest, training costs and demographic changes (Farhadi Rad, Mehralizade, \& Hassanvand, 2017). On the other hand, other studies show that the industry has been unable to benefit from the university programs due to policy-making and the economic situation (Gholami, Arasteh, Naveh Ebrahim, \& Zeinabadi, 2018) and that the industry should approach the universities to mediate this (Moghadas Noudeh, 2019).

\section{Table 1: Student Enrolment in Engineering, Manufacturing, and Construction}

\begin{tabular}{|c|c|c|c|c|c|c|c|}
\hline \multicolumn{2}{|c|}{ Country } & Denmark & Korea & Australia & Turkey & Germany & $\operatorname{Iran}^{3}$ \\
\hline \multicolumn{2}{|c|}{ Level 5: Short-Cycle } & 4120 & 181775 & 37758 & 357828 & 73 & 297628 \\
\hline \multicolumn{2}{|c|}{ Level 6: Bachelor } & 18943 & 481665 & 81792 & 468627 & 439879 & 654808 \\
\hline \multicolumn{2}{|c|}{ Level 7: Master } & 7448 & 29840 & 28655 & 83186 & 153717 & 199643 \\
\hline \multicolumn{2}{|c|}{ Level 8: PH.D } & 2142 & 17964 & 9094 & 20689 & 36500 & 24651 \\
\hline \multicolumn{2}{|c|}{ Total: Engineering } & 32653 & 711244 & 157300 & 930330 & 630169 & 1176730 \\
\hline \multicolumn{2}{|c|}{ \% Engineering Student } & $10 \%$ & $23 \%$ & $9 \%$ & $13 \%$ & $20 \%$ & $28.8 \%$ \\
\hline \multirow{4}{*}{ Gender } & $M$ & 23286 & 593092 & 121452 & 705833 & 492187 & 905265 \\
\hline & $\%$ & $71.3 \%$ & $83.4 \%$ & $77.2 \%$ & $75.9 \%$ & $78.1 \%$ & $77 \%$ \\
\hline & $\mathrm{F}$ & 9367 & 118152 & 35848 & 224497 & 137982 & 271465 \\
\hline & $\%$ & $28.7 \%$ & $16.6 \%$ & $22.8 \%$ & $24.1 \%$ & $21.9 \%$ & $23 \%$ \\
\hline \multicolumn{2}{|c|}{ Total: All field } & 312379 & 3136395 & 1774852 & 7198987 & 3091694 & 4073827 \\
\hline \multirow{4}{*}{ Gender } & $M$ & 136123 & 1828963 & 752638 & 3886107 & 1871596 & 2202231 \\
\hline & $\%$ & $44 \%$ & $58 \%$ & $42 \%$ & $54 \%$ & $52 \%$ & $54 \%$ \\
\hline & $\mathrm{F}$ & 176256 & 1307432 & 1022214 & 3312880 & 1499669 & 1871596 \\
\hline & $\%$ & $56 \%$ & $42 \%$ & $58 \%$ & $46 \%$ & $48 \%$ & $46 \%$ \\
\hline
\end{tabular}

Reference: OECD, 2017

\section{Theoretical foundations}

The employability construct was first used by the English economist Beveridge in 1909 and then was extended to the United States. The primary concept of employability referred to workers with high physical stamina; hence differentiating unemployed individuals who were unable to work from those who were able and in search of job opportunities (Grip, Loo, \& Sanders, 2004). Gazier (1998a as cited in Lindsay, 2009) explains the evolution of the employability concept within three different waves. The first wave of employability was during 1900-1940. Because individuals were divided into the two groups of employable and unemployable in this period, it was known as the 'Dichotomic Employability' approach. In the 1950s Forrier and Sels (2003) believe that one's working attitude and self-concept were the most important variables for defining employability. The second wave, from the beginning of the 1960s, focused on the measurement of the individuals' characteristics and the demands of the marketplace. The third wave, which began in 1980 and continued into the 1990s, included the triple concept of result-oriented, innovative, and interactive employability (Lindsay, 2009). In the 1970s, however, the approach was redirected from attitudes towards knowledge and

3-Institute for Research and planning in Higher education (Iran, 2017)

Farhadi Rad, H., Parsa, A., \& Rajabi, E. (2020). Employability of Iranian Engineering graduates: Influential factors, consequences and 
skills as the requirement for employability. In the 1980s, the organisation was emphasised instead of the individual. Employability was considered as the function of an individuals' flexibility within the organisation. In the 1990s, employability was perceived as a 'psychological contract' between the employee and the employer and the ability to find a job in the labour market.

Amiron, Latib and Subari (2019) suggest that in the fourth industrial revolution, the concept of employability has more complexity and includes different skills such as negotiation skills, cognitive skills, a service-orientation, team-work, emotional intelligence, shared decision-making, critical thinking ability, and complex problem-solving abilities. Briefly, the employability skills in the fourth generation of the industrial revolution include: Basic skills for the preparation of the workforce such as self-introduction and time-management abilities; Soft skills which include creativity, solving complicated problems, communicative skills and emotional intelligence; Technical skills which refer to the ability to create and promote job opportunities with an eye on the employability strategies and selection of goal-oriented instructions; and finally, the skills of creating entrepreneurship opportunities. Considering the existing innovative ways of providing financial support, creating a teamwork atmosphere, international communications and the availability of software platforms to enhance the benefits of decentralisation, it is probable that entrepreneurship opens up new windows for the youth around the world to overcome the traditional barriers to employability (Renjen \& Brown, 2018). Within the last century, the concept of employability most commonly used by economists has changed from a unidimensional construct focusing on the physical stamina, to a complicated construct. The scope of this concept went beyond the field of economics and a simple linear relationship between the individual and the job. It included the compatibility of the individual and organisation, multiple communications, the individual intelligence in interacting with the environment and creating and benefiting from special entrepreneurship opportunities. Therefore, the definition of employability has changed and new dimensions added in each period. For example, Hillage and Pollard (1998) defined it as having some basic capabilities to find a job. Since then other dimensions have been added such as, the graduates' ability to find a satisfactory job (Harvey, 2001), acquiring knowledge, skills, and attitudes, especially those which are expected by the employers (Brooks \& Youngson, 2015), and above all, understanding the needs and job abilities in the fourth generation of the industry (Azmi, Kamin, Noordin, \& Nasir, 2018).

When the economics of employment is framed within the context of the formation and expansion of Higher Education, the views of human resource theories' proponents are relevant. This theory insists on education as the fundamental element of economic empowerment (Bridgstock, 2009). As cited in Emadzadeh, (2015, pp, 18-26) the early advocates of Human Resource Theory like Adam Smith (1776) appreciated an educated person as an invaluable machine while Alfred Marshal (1950s) investigated the cost-benefit analysis of education. Schultz, Danison, and Baker (1960s) also evaluated the role of education in the economic growth. Generally, the intellectuals of this field believed that education increases the potential of employability via fostering the general and professional skills of working, improving the possibility of using the technology, changing the routines of task accomplishment, and enhancing the graduates' expertise (. Human Development Theory explores the relationship between employability and education and asserts that education develops abilities such as knowledge generation, professional preparation, and cultural knowledge (Sharif, et al., 2017).

Based on the economics of education theories, different models were proposed to increase the potential of students' employability. In these models, the relationship between the university and workforce market needs was emphasised more than before. For instance, one of the recent patterns, which encourages the culture of entrepreneurship and its promotion inside and outside the institution, is the Entrepreneurship University of Barton Clark (Clark, 2001). During 1998-2008, Barton Clark attempted to introduce a market-oriented, independent, and responsive pattern for the university by identifying entrepreneurship components. This notion is supported by UNESCO, which defined modern universities as places where entrepreneurship skills enhance the graduates' abilities and increase job opportunities (Azizi \& Shafiezadeh, 2013). An example of this is the annual one-day student workshop in Victoria, Australia, which enables graduates and craftsmen to interact.

Farhadi Rad, H., Parsa, A., \& Rajabi, E. (2020). Employability of Iranian Engineering graduates: Influential factors, consequences and strategies Journal of Teaching and Learning for Graduate Employability, 11(1), 110-130. 
In this workshop, students get acquainted with industry leaders and peers to gain useful insights for working in the real world, exchanging views and visiting real workplaces (Lock \& Kelly, 2020). This example shows the importance of universities incorporating entrepreneurship into the curriculum to enable their graduates to better fit the current concepts of employability (Azmi, et al., 2018). The preliminary review of the theoretical literature highlights the importance of attending to the socialeconomic role of the society in developing the students' employability.

Therefore, the research questions underpinning this study are:

- What factors affect the employability of engineering students?

- What are the benefits of their employment for the country?

- How can we improve the employability capacity for engineering graduates?

\section{Methodology}

Since the issue of engineering graduates' employability is a context-oriented issue, a qualitative research model based on Strauss and Corbin's (1998) grounded theory (systemic approach) was used in this study. Using this approach, the researcher can assign meaning to the data through thorough analysis and then present a framework for explaining the phenomena (Sando, 2018). In this method, the researcher is actively and directly involved and by constant comparison of data and conscious and goal-oriented selection of the best participants, investigates the hidden aspects of a phenomenon and proposes a theory without relying on the existing theories (Bazargan, 2018). As discussed in the theoretical foundation section of the present study, the phenomenon of making students employable is not a simple and unidimensional issue. Therefore, the model used to explain the employment complexities of engineering graduates required comprehensive and detailed attention to the phenomenon in the real context. The use of grounded theory enabled the researcher to draw a better picture of the reality through constant comparison of the data.

\section{Participants}

In the purposive sampling technique, the researcher defines the intended features a priori and then finds the right participants accordingly (Johnson \& Christensen, 2016). In this case, the participants were recruited purposefully among the expert curriculum and education designers of the higher education, employees, university lecturers, and graduates of different engineering disciplines. The snowball technique was used in identifying the participants who were contacted by phone. The participants were informed that their details would remain confidential and that technical notes would be referred back to them before analysis. The office staff of the university or company where the participants were located assisted in the negotiation of an appropriate time and place for the interview to be conducted. Initially researchers contacted 43 people and subsequently 15 participated in the in-depth interview. The participants are described in Table 2. Interviews usually lasted between 45 minutes and 2 hours with the average duration being 65 minutes. In all cases, the interviewees' consent to save the audio file, and time and place of the interview were obtained ${ }^{4}$.

${ }^{4}$ This research has the code of ethics (EE/98.24.3.58242/scu.ac.ir) from Shahid Chamran University of Ahvaz.

Farhadi Rad, H., Parsa, A., \& Rajabi, E. (2020). Employability of Iranian Engineering graduates: Influential factors, consequences and 
Table 2: Description of Participants

\begin{tabular}{|c|c|c|}
\hline No. & $\begin{array}{l}\text { Interview } \\
\text { Code }\end{array}$ & Participation Competencies \\
\hline 1 & PED1 & $\begin{array}{l}\text { University professor, educational planning specialist, organizational consultant of } \\
\text { training, improvement and development, employment and productivity consultant, } \\
\text { having diverse publications related to employment and entrepreneurship of the } \\
\text { graduates }\end{array}$ \\
\hline 2 & PEN1 & $\begin{array}{l}\text { The faculty member of Mechanical Engineering, university graduate, top inventor, the } \\
\text { office manager of the industry and university relations, entrepreneur, experienced in } \\
\text { directing industrial projects, and the manager of a knowledge-based company }\end{array}$ \\
\hline 3 & PED2 & $\begin{array}{l}\text { University professor, planning and curriculum designing specialist, director of the } \\
\text { university educational planning, students' internship supervisor in industry and labor } \\
\text { market, designer of students' professional skills }\end{array}$ \\
\hline 4 & PES & $\begin{array}{l}\text { The faculty member of geological engineering, former director of the Growth-center } \\
\text { and knowledge-based companies, Students' employment consultant, petroleum and } \\
\text { energy activist, and the manager of a knowledge-based company }\end{array}$ \\
\hline 5 & PS & $\begin{array}{l}\text { The faculty member of Chemistry Science, former director of the Science and } \\
\text { Technology Park and Growth-center of the province, member of employment council }\end{array}$ \\
\hline 6 & PEN2 & $\begin{array}{l}\text { The faculty member of Architecture, member of the Engineering System Organization } \\
\text { and the Educational and Research Council of the Engineering System Organization, } \\
\text { having the experience of research work in the industry, member of employment council }\end{array}$ \\
\hline 7 & PEN3 & $\begin{array}{l}\text { The faculty member of Civil Engineering, having the experience of working in the } \\
\text { industry in the form of research projects, Vice chancellor for university planning, Head } \\
\text { of civil engineering department, students' internship supervisor }\end{array}$ \\
\hline 8 & M1 & $\begin{array}{l}\text { Employee, PhD holder of Bio-system Engineering, owner of a knowledge-based } \\
\text { company, private-section activist, and provincial entrepreneur }\end{array}$ \\
\hline 9 & $\mathrm{M} 2$ & $\begin{array}{l}\text { Employee, PhD holder of Mineral Technology, top entrepreneur, member of the board } \\
\text { of directors of the Engineering System Organization, former director of the Engineering } \\
\text { System Organization, member of the board of directors of the Industry House of } \\
\text { Khuzestan Province }\end{array}$ \\
\hline 10 & PEN4 & $\begin{array}{l}\text { The faculty member of the Civil Engineering, former consulting engineer in designing } \\
\text { structures and supervising the execution of industrial projects, internship and } \\
\text { entrepreneurship consultant, director of knowledge-based company }\end{array}$ \\
\hline 11 & PEN5 & $\begin{array}{l}\text { The faculty member of Civil Engineering, the private-section activist, manager of a } \\
\text { construction company, consultant of construction projects }\end{array}$ \\
\hline 12 & PEN6 & $\begin{array}{l}\text { The faculty member of Mechanics, having the experience of working in industrial } \\
\text { research projects, director of knowledge-based company }\end{array}$ \\
\hline 13 & M3 & $\begin{array}{l}\text { Employee, former head of Education, Research and Technology Department of Industry, } \\
\text { Mining and Trade Organization }\end{array}$ \\
\hline 14 & M4 & $\begin{array}{l}\text { Employee, having the experience of working with the Growth-center of the Jahad } \\
\text { University, former head of Business and Employment office of Jahad University, } \\
\text { Entrepreneurship Institution consultant, Entrepreneurship Commission member of } \\
\text { Chamber of Commerce }\end{array}$ \\
\hline 15 & PEN7 & $\begin{array}{l}\text { The faculty member of the Materials Engineering, former director of Industrial relation } \\
\text { of the university, former member of university policy commission, private-section } \\
\text { activist }\end{array}$ \\
\hline
\end{tabular}

Farhadi Rad, H., Parsa, A., \& Rajabi, E. (2020). Employability of Iranian Engineering graduates: Influential factors, consequences and strategies Journal of Teaching and Learning for Graduate Employability, 11(1), 110-130. 


\section{Data collection (Interview protocols)}

A semi-structured interview was used for the data collection. The main aim of the interviews was to gather data surrounding the issue of the employability of students which could then be used to propose a theoretical model. The interviews were administered based on the following schedule.

\section{Pre-interview}

Initially the participants were contacted by phone and during this conversation the researchers explained the purpose of the study, outlined the process of recording the interviews, answered participant's questions and set the time and place for the appointments which were then confirmed through the office of the organisation. Also important at this stage was the development of rapport and trust between the interviewer and participants.

The interview questions, which were developed from the theoretical literature on employability and previous relevant research were presented in 2 parts: semi structured questions and open discussion.

The semi structured section included questions such as:

- What causal factors affect the employability of graduate engineers?

- What are the contextual factors which affect the employability of graduate engineers?

- What intervention factors might affect the employability of engineering students?

- What strategies do you think would affect the employability of engineering students?

- What are the consequences of the difficulties faced by engineering students regarding their employability?

The open section of the interview was expected to be a free discussion of the issues which arose during the semi structured section. For example, arising from the question on contextual factors was a discussion of how sanctions have affected the employment of Iranian engineering students.

\section{Interview}

The interviews began with the researcher introducing the purpose and the stages of the study, followed by a short review of the abilities and weaknesses of the graduates, and other problems related to their employment. The semi structured questions were then presented with participants having an opportunity to elaborate. Following this, the researcher asked open-ended questions based on the introduced topics. The approximate time for each interview was 65 minutes and with the agreement of the participants all interviews were recorded ${ }^{5}$ via voice recorder.

\section{Discussion}

During this section participant were given an opportunity to further explain their views.

\section{Post- Interview}

Following the interview, the audio files were converted to word files by the researchers. Technical notes based on the interviews (making the initial tags for the technical analysis) were prepared and returning to the participants to validate the data. The final version of the interviews was then prepared for coding purposes.

\section{Data analysis}

To analyse the data, open, axial and selective coding techniques were utilised (Strauss \& Corbins, 1998). After each interview, a report was prepared and the coding process started by the researchers (see Tables 3 and 4). To validate the findings and confirm the discussions of participants'

\footnotetext{
${ }^{5}$ Interviews were conducted by Elaheh Rajabi, a member of the research team
} 
opinions, the reports were returned to interviewees and were also checked by the researchers who were present throughout the interview process. Two doctoral students in educational administration were asked to participate as research collaborators (coders) and coded the interviews. The measure of stability (73\%), was obtained based on the following formula. If the stability is greater than $60 \%$, coding is confirmed and it can be claimed that the stability of the interview is acceptable.

$100 x$

\section{Number of Agreements $\times 2$}

Total Number of Codes
Percentage of Inter-

subject Agreement

\section{Open coding}

First, each 'meaning unit' of the interview was selected, tagged, and named. Table 3, partially shows the process of moving from the data to abstraction. In general, from 15 interviews, 360 open codes were extracted, some examples of which are presented in Table 3.

\section{Table 3: A Sample of Open Coding (extracted from an interview)}

\begin{tabular}{|c|c|c|}
\hline No. & Sentences (extracted meaning units) & Open codes (tags) \\
\hline 1 & $\begin{array}{l}\text { In the engineering disciplines reviewing the syllabus } \\
\text { is an essence. }\end{array}$ & $\begin{array}{l}\text { Reviewing the syllabus of } \\
\text { engineering courses }\end{array}$ \\
\hline 2 & $\begin{array}{l}\text { Universities are unaware of the needs and expertise } \\
\text { required by the labor market. }\end{array}$ & Identifying the needs of market \\
\hline 3 & $\begin{array}{l}\text { Universities act based on their own abilities and the } \\
\text { plans of the Ministry of Education }\end{array}$ & University-based Instructions \\
\hline 4 & $\begin{array}{l}\text { The relation between theoretical instructions and } \\
\text { practical instructions is not logical and needs } \\
\text { revision }\end{array}$ & $\begin{array}{l}\text { The congruency between } \\
\text { theoretical and practical } \\
\text { instructions }\end{array}$ \\
\hline 5 & $\begin{array}{l}\text { The first step in increasing the employability of the } \\
\text { students is to give hope }\end{array}$ & $\begin{array}{l}\text { Enhancing the students' hope and } \\
\text { motivation }\end{array}$ \\
\hline ... & $\ldots$ & $\ldots$ \\
\hline
\end{tabular}

\section{Axial coding}

To use concepts that better explain the employment phenomenon of engineering graduates, open codes, which are more semantically similar, were categorised in the form of axial codes. The axial codes are abstract concepts derived from the real data that pave the way for the development of the theory. Table 4 depicts a sample of the extracted axial codes from the related open codes. In total, 360 open codes were converted to 37 axial codes. 
Table 4: How to make connections between open and axial codes (Extracted from an interview)

\begin{tabular}{|c|l|l|}
\hline $\begin{array}{c}\text { Number of } \\
\text { open codes }\end{array}$ & \multicolumn{1}{|c|}{ The sample of open codes } & \multicolumn{1}{|c|}{ Axial Codes } \\
\hline 4 & $\begin{array}{l}\text { Inadequate cooperation of University and Industry, } \\
\text { lack of serious attention to the extracurricular courses, } \\
\text { industry visits without the presence of the professor }\end{array}$ & $\begin{array}{l}\text { Inadequacy of industry } \\
\text { visits }\end{array}$ \\
\hline 5 & $\begin{array}{l}\text { The congruence of the graduates with the needs of the } \\
\text { market, needs analysis of the required professions of } \\
\text { the country, providing needs-based instructions, } \\
\text { employing professors based on real needs, including } \\
\text { practical skills as a requirement of employment for } \\
\text { university professors }\end{array}$ & $\begin{array}{l}\text { Regulating the } \\
\text { curriculum with the } \\
\text { labor market needs }\end{array}$ \\
\hline$\ldots$ & $\ldots$ & $\cdots$ \\
\hline
\end{tabular}

\section{Selective coding}

Selective coding means choosing a general category that covers all the axial codes. The analyses in the current investigation revealed that students' employability is under the influence of the socioeconomic state of society. As shown in Figure 1 and described in the conclusion section, many national and international factors impact on engineering graduates' employability in Iran and most of them are not able to be influenced by the university system. Therefore, it is not possible to explain it via internal-university processes. Employability as an 'over-university' phenomenon was chosen as the selective code. Refining the codes and constant analysis of the theory are all based on the researcher's theoretical saturation, i.e., a stage in which no new insights and ideas are generated (Mohammadpour, 2013).

\section{Findings}

To report the findings of the study two methods were adopted. The first was the Inductive method in which the researcher first presents all the axial codes separately and then, through reasoning and discussion, explains their importance in the final model. The second method was the Deductive method in which the researcher first presents the finalised pattern that is the theory extracted from the data, then gives the explanations and discussions for each axial code. In the present study, the second method was utilised for representing the findings. Therefore, in the first part, a paradigm structure is given (Figure 1) and then, the influential factors on the students' employability are analysed and explained. As can be seen in this structure, all the axial codes extracted from the data are classified based on five main axes (causal, context, intervening conditions, strategies, and consequences). 


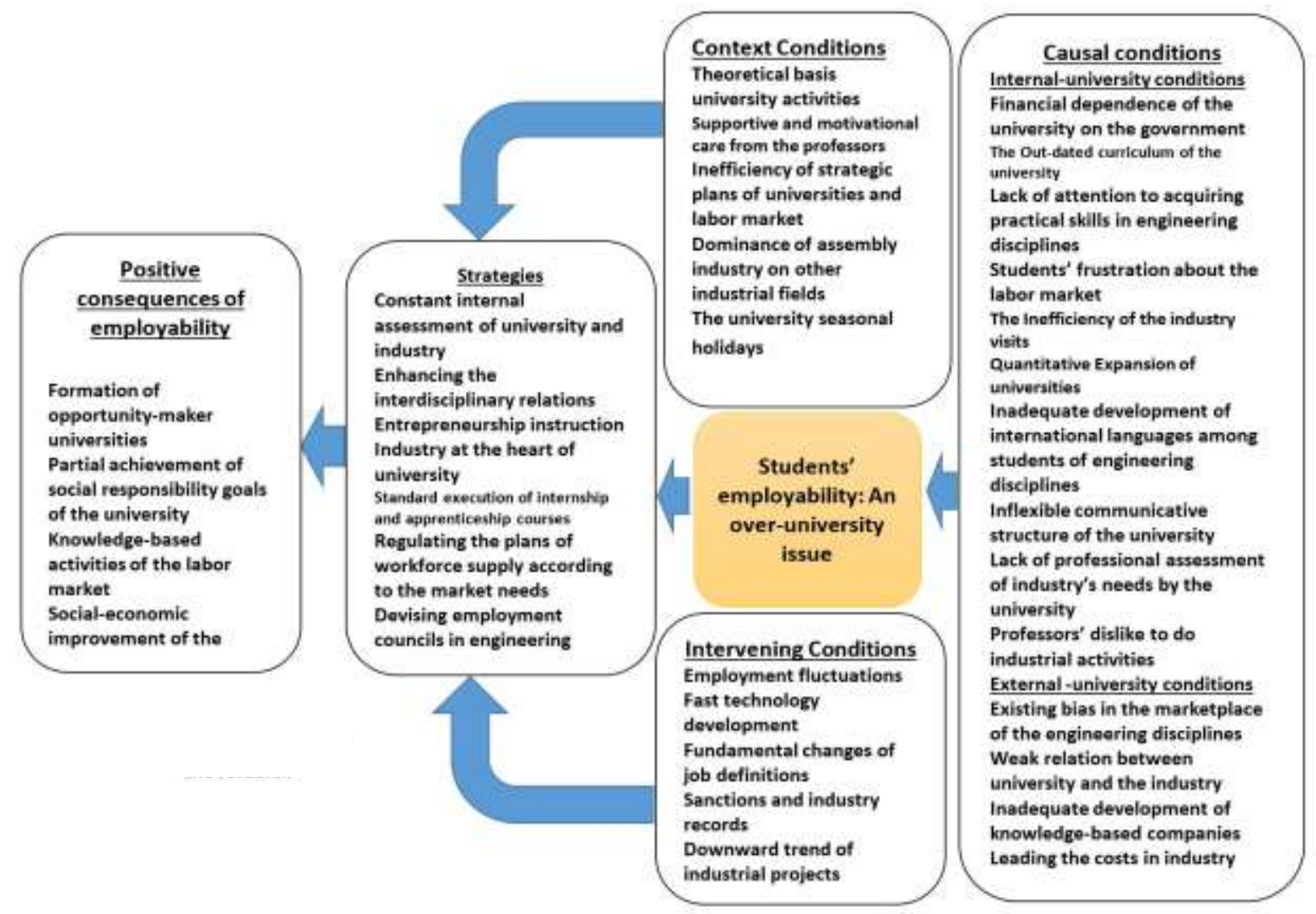

Figure 1: Final Model from the Research

\section{Discussion}

Since the overall aim of the current study was to provide a model for the explanation of engineering students' employability, in this section the influential factors, consequences and strategies are analysed. The influential elements occur at different levels; some have direct effects that are called causal factors and are divided into two groups of university internal and university external factors. Some provide the context for employability, such as economic conditions which are difficult to change, but can be kept in mind while planning. Other factors are unexpected, such as the sanctions which cause differences suddenly via intervening with other factors and affecting the students' employability.

\section{Influential factors}

\section{University internal factors}

- Lack of financial independence

An inherent problem from an intra-system perspective is that in Iran, the universities have not been very successful in decreasing their financial dependence on the government. This is not surprising given that the financial dependence of the universities on the government is a major and historical policy in Iran. That is, in Iran, the government is the main finance supplier of the university sector. The prerequisite for granting credits to universities is based on the number of students entering universities. This situation has affected the students' employability in different ways. Accepting students with low standards can be used as a tool for convincing government officials to grant more credits. However, if providing quality instruction, and enhancing research and social services are only achieved by bargaining for more financial resources, these may not be achieved, particularly if

Farhadi Rad, H., Parsa, A., \& Rajabi, E. (2020). Employability of Iranian Engineering graduates: Influential factors, consequences and 
improving the quality instruction is not valued by the state stakeholders. Indeed, university standards and internal relations might be a low priority to stakeholders. As a result, not only employment but also other university missions may be marginalised as indicated in the following comments.

Unfortunately, our state universities are supported by the petroleum incomes. That is why, because of their dependence on the government, other things are not of significance to them (PES).

The biggest problem now is that a great part of industry and employment is controlled by the state. It is a state university, too. Both industry and university are fed by the government; that means the existence of university and industry is not connected (PEN5).

Since the university is a state organisation and the government supplies the entire budget, any discipline taught in the university would receive the budget based on the number of students and the educational grade (PEN3).

- Curriculum

An important part of the problem of employability is related to the engineering curriculum. The curriculum is the content and the official plan from which the learners receive instruction, engage in learning strategies, acquire different skills or develop their views and values. Today, the industry is experiencing its fourth generation, thus preparing the workforce with an eye to its criteria requires an overhaul of the syllabuses to make them appropriate and up-to-date. The lack of up-to-date educational content leads to the development of graduates who are not very efficient in the labour market as indicated by the following comments from participants.

Unfortunately, the problem is that teaching or not teaching these subjects we already do in the university does not make a difference; just like in high school and college (PEN2).

We, as the faculty members of the Engineering Faculty, have the responsibility to teach subjects which are dictated to us by the Ministry. Even the syllabus is given to us and as teachers, we have to follow the framework (PEN7).

Conditions are different in different fields of engineering. For example, in the computer sciences, the changes happen so fast, so the teacher needs to be much updated to be able to teach the skills in line with the recent changes (PEN3).

- Lack of work related context

Universities have not been very successful in providing engineering students with appropriate 'skills training'. The real labour market needs graduates who have examined and practiced their knowledge at least in a laboratory. It is not inclined to recruit students who have only collected scientific information. Although providing opportunities to develop knowledge in practical situations is expensive, if universities invest in skills training alongside the theoretical development, the graduates would be more prepared to enter the labour market. Following are comments related to this.

...the number of modern, strong and practical labs, and good workshops and atelier are few, and there are only some ineffective theoretical courses which suffer from weak instruction skills (PEN2).

The engineering workshops do not present skills adequately, and the equipment is not enough and matched to today's industrial needs (PED1).

To adequately relate to the industry and labour market, and to enhance the quality of instruction, 'academic tours' in industrial centres were proposed and defined as a useful tool which would increase the employability of engineering students. The real life experiences of the participants in these tours suggests that the number of academic tours in the engineering disciplines is not sufficient, and industrial centres do not warmly welcome the visitors. Hence, these tours which open

Farhadi Rad, H., Parsa, A., \& Rajabi, E. (2020). Employability of Iranian Engineering graduates: Influential factors, consequences and strategies Journal of Teaching and Learning for Graduate Employability, 11(1), 110-130. 
up a window for the students to be acquainted with the real challenges and activities in the workplace are conducted with little attention to a quality experience. One participant commented as follows.

The academic tours should be planned in a way that for each course in each term, students visit three to four companies and get familiar with the latest technology and industrial issues. However, as a faculty member, I am responsible to manage these tours, the transportation, and make all the things prepared (PEN7).

The external environment of the university is complex, unstable, problematic, and unpredictable, and it is possible to have only very limited impact over it (Mirkamali \& Farhadirad, 2013). Industrial centres have diverse and variable needs and considering technological advancements, the needs are short-term and change quickly; therefore, engineering graduates should acquire abilities and competencies that are in congruence with the variable needs of the environment. However, due to the 'inflexible structure of the university' it has not been possible to devise an efficient and flexible relationship with the labour market. In the bureaucratic system of the university, incorporating a 'professional needs analysis' in planning is rarely considered.

The structure of the university is not dynamic. Neither are the principles flexible enough. The university is behaving very strictly. We claim that the industry is connected through the university. Unfortunately, I think this connection is broken now (PEN2).

The force of law, policy-making, and planning is now on universities to strengthen the ties of relation with labour market and industry (PEN6).

- Student quality

'Quantitative expansion of universities', especially applied science and technology universities, and non-profit and Islamic Azad universities, has increased the number of engineering graduates with the lowest standards of education and research. The consequence of such an uncontrollable supply is the inability of the private and state organisations to absorb graduates who entered engineering fields to increase their employability chances, which in turn leads to their frustration and demotivation. This frustration causes students not to participate seriously in academic learning.

When a person does not have the necessary interest, talent, and motivation, he says to himself, what is the use of these courses in my life? Naturally, this person cannot be effective (M4).

...there is no hope among engineering students for future employment. So, the student thinks he/she is doing a useless job to study and loses his/her motivation and attempt (PES).

Acquiring general skills, especially learning English as the international language is one of the preferences that exerts an important influence on the graduates' employability in the country or abroad. In addition to the access to the scientific resources, having mastery over English would enable the students to read machine brochures, access the websites of manufacturers, and benefit from other online and offline instructions. For the reasons mentioned earlier, such as the quantitative expansion of universities, engineering students are far from being competent in general skills.

General skills like English language fluency can be very helpful for the employability of the students based on our current economic conditions (PEN5).

Students are weak in learning English, and we have few multilingual students who can work abroad (PEN2).

- Teaching practices

University professors as practical models have a significant role in influencing students' attitudes. However a tendency toward theoretical instruction and 'avoiding educational activities in industry and society' or practical application has emphasised the theoretical subjects, with no logical relationship between theory and practice being formed by the students.

Farhadi Rad, H., Parsa, A., \& Rajabi, E. (2020). Employability of Iranian Engineering graduates: Influential factors, consequences and 
...different factors including the difficulty and lack of transportation facilities to the industrial centres, as well as the inherent difference between working in the field and the official bureaucracy, have made the university professors reluctant to appear in the real context of the job (M4).

\section{University external factors}

- Bias in the marketplace

Though no one would deny the significant influence of the university internal factors on the employability of engineering graduates, there are also external factors to consider. One of these is the existing bias in the marketplace which encourages students to spend their energy and motivation on activities other than learning the skills and the requirements of working to win the job opportunities. This bias includes the biased assignment of industrial projects and biased relationships. Therefore, the students might think university training cannot qualify them enough for employment.

In Iran, projects are given to individuals, not teams. What seems more important than expertise is the relational closeness of the individual to the functionary (PED1).

We have the issue of ethnic groups which has permeated all walks of life. When you enter an office, you will be treated differently if you are from a specific ethnic group (PEN1).

- Relationship between industry and universities

The industry sector, as the most important area of practice for engineering graduates, is a place where scientific advancements should be applied. It seems that the number and the quality of the relationships between industry and university are indicative of the success or failure of graduates' plans for individual development. The lack of trust between these two organisations has caused many problems beyond the scope of the current study. However, the 'reciprocal relationship' between university and society needs to be redefined to include the employability of students. Also, inadequate development of knowledge-based companies and weak support of start-ups do not enable talented and innovative students to try their abilities and skills.

...the industry believes that the university instructions are not in line with the industry needs. There are several requirements and skill which a student should develop via internship after receiving instructions from the university (PES).

...the industry we are working with now goes back to three or four decades ago in Europe. Research and development centres should be created, which are absent now (M3).

...there are not enough big knowledge-based companies to employ workforce when I am graduated (PEN7).

- Recruitment strategies

One of the university external factors that is very important for graduates' employability is the way the industry looks at the workforce and selects in the recruitment process. Today, industry in Iran, relies greatly on the 'cost management strategy'. In the cost management strategy, the industry seeks to use individuals who can produce and be profitable at the lowest cost and in the shortest possible time. The current industries are not welcoming or valuing education and do not seek highly qualified graduates.

...the industries we have do not need education and science. They don't need an educated workforce (PS).

...industry needs a technician or an engineer who can work with the machines; any person with some amount of instruction would be able to do that (PEN3).

Farhadi Rad, H., Parsa, A., \& Rajabi, E. (2020). Employability of Iranian Engineering graduates: Influential factors, consequences and 
- The perceived role of universities

The theoretical basis of university activities is evident both in policy and practice. In most disciplines, more than $80 \%$ of the syllabus is theoretical and a brief review of the syllabus of the engineering discipline would confirm this. This means that theoretical instructions are the top priority for policymakers. Moreover, the high cost of teaching practical skills, of supplying materials and equipment, of conducting workshops, and the difficulty of connecting with the world outside the university have all led the universities to prefer theoretical instructions. There is also a strong view that the student can develop practical skills outside the university and that the university is not responsible for the employment skills; it is a place for dealing with deep scientific challenges.

...at the university, we spend most of our time on theories, even worse, we spend our time on things that the student must have learned at school like basic mathematics (PEN7).

...some subjects were included in the syllabus of the engineering discipline before which could be useful, but during the recent decades, these subjects are removed from the syllabus and were substituted by more theories. This can severely damage the practical skills of engineering students (PEN4).

The skills can be learned from other sources for example from the institutions which are skilloriented. However, I think, the university should deepen the students' understanding of the field. We should not expect universities to increase the employability (PED2).

In the universities in Iran, the supportive and motivational endorsement of professors and students for doing industry related activities is rare. In some cases, the professors have been criticised for their external activities.

Real-life context is required, for example, if a professor decides to instruct the students based on the project-oriented PBL. But it is not possible because the facilities are not available (PED2).

...field projects are difficult, but the university doesn't provide any support. Even doing the rudimentary tasks of preparation for outside the field activities most of the time faces major difficulties (PEN7).

- Lack of strategic planning

The issues around the employment of engineering graduates are made worse by the fact that universities and industry are not cooperating in considering scenarios for the future and investigating probable needs for the future. Neither the university nor the engineering industry has a coherent strategic plan that everyone is committed to. Weak strategic plans of university and industry causes confusion for students when considering their future.

The university should have strategic plans, and create scenarios. The university should prospect for different conditions in the future. But these plans are scare, and if any, they do not play a key role (PED2).

....we need to deploy futures studies in the industry however, we don't. Even if there is any plan, it is under great influence of political and social issues to the extent that it loses its predictability (M2).

Our industry is based on old structures and technical criteria with no future studies. This is the problem (PES).

- Lack of innovation

The dominance of the 'assembly' industry on other industries is another fundamental factor that affects the employability of engineering graduates. Normally, with the emergence of industrial revolutions, the needs of the labour market and the nature of university disciplines would change and the educational standards would be refined based on these changes. However, industry in Iran is imported and its relationship to education is at a low level. It is not productive, dynamic, and

Farhadi Rad, H., Parsa, A., \& Rajabi, E. (2020). Employability of Iranian Engineering graduates: Influential factors, consequences and strategies Journal of Teaching and Learning for Graduate Employability, 11(1), 110-130. 
dependent on innovative graduates. Therefore, even if the universities provide high-quality education, the engineering industry does not have enough potential to absorb them.

Ours is not a real industry, but only companies. When we say industry we mean it is selfinitiative and self-productive (PEN3).

Ours is the industry of assembly. That is why our industry does not dare to change. Since it is not a dynamic industry, it needs good operators, not good engineers (PES).

- Cultural factors

The University seasonal holiday, especially during the summer, is part of the students' lives. In this period, which is sometimes extended to three months, students' engagement with their normal educational commitments, especially practical instruction, is impeded. For example, most of the engineering students' internships are in the summer; but due to the university closure and the absence of the professors, there is no supervision of the students' internships. Industry and the market do not care about internships because they are not seriously monitored by the university, and they are not assigned specialised work.

The professor requires an internship from the students during the summer. With no supervision, the student's internship form would be signed by the industry certifying that the student has done 80 to 120 hours of internship, while in reality, he has only attended the field twice. Then this form is signed by the student's supervisor with no instruction being taken place (PEN7).

\section{Intervening conditions}

\section{International sanctions}

The intervening factors refer to unpredictable conditions that have garnered little attention from the policymakers. The most important intervening factor affecting the industry and the labour market in Iran is international sanctions. Both university and industry are largely the victims of policies over which they have no control. Due to the high risks caused by sanctions, international investments declined which led to a decrease in industrial projects. According to the records of the Parliament research centre with the cooperation of economic organisations in Iran, the international sanctions during 2012 had serious effects on graduates' employability (Khadem Alizadeh, Amadeh, \& Baghalian, 2014). Labour market fluctuations and industry indecisiveness that were the consequences of the sanctions also caused students to lose their motivation.

If the economic conditions of the society ameliorate and the sanctions are lifted, the labor market would seek workforce and graduates, and when students explore these job opportunities, they would improve their skills (PEN4).

The engineering market is largely a function of macro policies and the economy. It means any improvement in the market would flourish in the engineering market. However, there are two marketplaces, domestic and foreign. For example, our steel industry which exports products is now experiencing great difficulties due to the sanctions (PEN5).

Most of the civil projects are pending now and no new projects are being planned, and if any, they are past unfinished projects waiting for the budget (PEN4).

The labor market in Iran is not based on the logic of economics. Most of the companies do not follow a straightforward routine of production. Therefore, they need to make drastic functional changes to survive (PED1).

\section{Technological development}

The world we live in experiences fast technological advancements in which the growth of science has caused many complexities in different fields and has led to the emergence of modern technology. The rapid technological changes require individuals with high levels of creativity and education and are able to move alongside these changes and handle unexpected circumstances. Universities are

Farhadi Rad, H., Parsa, A., \& Rajabi, E. (2020). Employability of Iranian Engineering graduates: Influential factors, consequences and 
not as dynamic as the industry and cannot synchronize themselves with fast technological advancements. These changes have revolutionized the nature of many professions, and require the graduates to say abreast of these changes.

I believe that the university is highly efficient, but drastic changes are taking place in different industrial fields, most of which have foreign sources. That is why the university should go in line with the scientific, industrial, and social changes. The university curriculum should be responsive to social expectations (PED2).

...we have to keep in mind that the scientific scope expands two times each year, and the changes happen so fast that the older paradigms cannot be responsive anymore (M4).

...now, you cannot find a job in which you can work for 30 years, especially if the job is technology-based because the changes occur very fast (PS).

\section{Consequences of the influential factors on employability results}

The universities in Iran are conservative and try to avoid comparisons with other national and international level universities in order to receive state financial support. To survive, they increase factors such as physical space, number of students, number of professors and staff, instead of attending to more important indices such as the fulfilment of national and regional needs, science production, and international credit. Improving the engineering students' employability potential would speed up the formation of an opportunity-making university education because employability is a complex structure that goes much beyond acquiring basic skills.

When the university improves the employment potentials, instruction standards would improve, too, and the assessment system would be more criterion-based. The students' responsibility for learning is also increased (PED2).

... the least result of increasing the graduates' employability is the popularity of the university, and this popularity can also be helpful for the university in receiving the non-state financial support (PEN1).

Of the consequences of increasing the employability of the engineering graduates we can name motivational growth, ability enhancement, and an increase of the social trust to the university as a popular brand (PEN2).

Improving students' employability would pave the way for professional and qualified individuals to enter society. Enabling people to be responsible for their environment in addition to professional task performance is part of the social responsibility of the university. Improved employability sheds light on the expansion of knowledge into industry, strengthens the trust between industry and the university, and allows both the university and industry to flourish. Therefore, knowledge-based activities of the labour market show the way of social prosperity in economic and social areas. Moreover, a dynamic economy is more likely when it is based on the latest and advanced knowledge that have been acquired in constant interaction with local industries and communities.

Self-satisfaction is the best feeling resulted from the individual's employability, because, satisfaction would influence the whole society (PES).

The marketplace would also benefit from the improved employability when more professional workforces enter the society, the labor market, and the industry; in other words, more qualified individuals are absorbed by the marketplace and individuals would be better and more efficient citizens (PED2).

Increasing the number of efficient workforces would generally improve the efficiency of the industry and society. Therefore, the knowledge-based economy would grow faster, individuals would become innovative and the whole system benefits from it (PEN5).

Farhadi Rad, H., Parsa, A., \& Rajabi, E. (2020). Employability of Iranian Engineering graduates: Influential factors, consequences and strategies Journal of Teaching and Learning for Graduate Employability, 11(1), 110-130. 
The universities should constantly undertake self-assessments and observe the labour market needs. This would help them be more realistic in considering issues such as the teaching and learning process, the educational content, the educational system, the professors of the engineering courses, and education and research facilities and equipment.

The university should also assess its performance, and it should not be limited to the assessment of learning, the scores, average, and certification. It means that the university has to have both internal and external assessment criteria and examine whether the graduates are qualified and efficient enough to find suitable jobs (PED2).

Both the university and industry should assess their performance to be able to interact with each other concerning the engineering students' employment (M4).

The interdisciplinary nature of different sciences is inevitable and indicates the close relationship between similar and even different areas of inquiry. Today, unidimensional proficiency would not make the graduates employable. For example, in addition to his profession, a mechanical engineer needs to have a partial mastery over computers, good communicative skills, and know about the biological sciences. On the other hand, a student cannot be omniscient. Although some universities permit the study of two different majors simultaneously, this is not the main solution. Therefore, the universities can strengthen the interdisciplinary communications as a key strategy for solving one aspect of the graduates' employability issue.

Planning interdisciplinary courses and providing the engineering students with the possibility of studying the courses of other majors will help develop employability skills (PS).

Fostering skills should be multidimensional and not limited to one field of study (PEN2).

The university should create a deeper understanding of a scientific field and invest in the interdisciplinary and meta-disciplinary skill development and scientific and technical functions of individuals (PED2).

Entrepreneurship Instruction is one of the strategies that mitigate the difficult conditions of Iranian society today. By promoting an entrepreneurship culture and forming entrepreneurship approaches among the students and professors, organising science and technology parks, establishing growth centres, and start-ups, the conditions become more conducive to a university and society connection. Under the influence of entrepreneurship, not only are economic values created, but also social, political, and cultural developments emerge.

...teaching entrepreneurship to the students of engineering causes skill development during the course of studying and prepare them for creating entrepreneurial ideas (M1).

Both the students and the professors should perceive the opportunities are limited. Therefore, when someone is a student, he/she should seek opportunities (PED1).

The student should learn the entrepreneurship skills, perceive the professional life, and plan the ways to achievement (M4).

The industry and engineering faculties cannot work separately unless being fed by an external resource (like the government). The university should be present in society, with no barriers to responding to the needs of society. Industry at the heart of the decisions of the university is a sign of modern universities that improve students' employability through presenting them with real job challenges and the realities of industry.

...in addition to introducing scientific findings, different conferences and gatherings provide the opportunity to acquaint the artisans with the job applications. The Week of Research should not be held symbolically. It should be held as a workshop of real working context (PEN7).

Farhadi Rad, H., Parsa, A., \& Rajabi, E. (2020). Employability of Iranian Engineering graduates: Influential factors, consequences and 
The real connection between the university and working is formed through internship workshops. Standard implementation of apprenticeship and internship courses would help students acquire experience under the supervision of some experts. They can also develop responsibility, cooperation, and self-confidence needed for the real world of working. On the other hand, active participation in the society also leads to a better understanding of the needs of the society and therefore the coordination of labour supply and demand. When a field of study has a very limited market, not all cities should absorb applicants because of the cost of running the field, or the presence of relevant professors.

In the internship courses the ideas is to become familiar with the labour market, and acquire the skills which are practical (PEN3).

If universities think rationally and realistically, then they should decrease the absorption capacities of the courses that are already saturated in the market and consider the students' employment (PEN3).

Another strategic factor affecting the employment capacity of engineering students is the formation of employment counselling centres at the School of Engineering. Establishing employment counselling centres can familiarise students with the current and future job market, show the students their skills and interests, introduce them to job opportunities related to each field, and guide them in their pursuits.

Some centres should be established in the universities to enable students to find and develop their interests there. For example, in the Materials Department, some of the professors have the experience of industrial work; make an industrial counselling centre for the students of Metallurgy to receive guidance before graduation (PEN7).

One of the biggest problems for engineering graduates, according to the Statistical Center of Iran, is finding a job appropriate to their skills and expertise. The consequences of unemployment are serious for the graduates who have spent a lot of time and money to study at a university with the expectation of employment at the end. Society also expects universities to educate skilful and professional human resources after receiving financial support. One of the intra-organisational weaknesses of higher education in Iran is that the engineering educational plans in universities are not systematically evaluated. Engineering is, in fact, a world system, and teaching engineering should prepare engineers in accredited instruction and systems of education. Despite the recruitment of students at all levels (undergraduate, master, and doctoral), and the endeavour for high-quality instruction based on a combination of CDIO, ABTE, EUR-ACE criteria in universities of Iran, the engineering education programs in Iran are not independently evaluated as is the case in the world. (Memarian, 2011).

The results of the current study show that the employability of engineering graduates' is affected by a multitude of factors which can be classified into the three categories of personal skills, university internal plans, and university external factors. Most of the factors identified by the current study are in line with the results of other studies, for example, personal skills, attitudes and professional training (Nguyen, Yanagawa, \& Miyazaki, 2005), soft skills and personal attitudes (Nillson, 2010), cultural backgrounds (Gribble, 2014), the collaboration of university and industry (Gabureanu \& Serbanescu, 2017), necessities of the workplace (OECD, 2010), and employers' attitudes towards the engineering graduates' skills (Harun et al., 2017). One of the issues that have greatly affected the engineering graduates' employability is international sanctions. These sanctions have caused a decrease in the import rate of capital goods (Ezati \& Salmani, 2014) which constitute the infrastructure of the industries in Iran. Technological sanctions, limitations of financial transfers, sanctions of the Central Bank and oil and gas sales, the prohibition of exchanges of precious metals and gold, and blocking funds are among the issues that directly and indirectly affect higher education and the market place in Iran. Another issue in this regard is the mechanism of student recruitment at the higher education level. According to Table 1, 28.8\% of Iranian students are studying one of the engineering majors. Therefore, based on the higher education policies in Iran,

Farhadi Rad, H., Parsa, A., \& Rajabi, E. (2020). Employability of Iranian Engineering graduates: Influential factors, consequences and 
more than $99 \%$ of these are recruited from the local students of Iran who probably seek their occupational future in this country.

\section{Conclusion}

According to the results of the present study, then, one can conclude that the employability of engineering graduates in Iran is not merely a function of university internal factors, but that other factors are also involved. While some factors are related to the university and its internal mechanisms, others are related to the university's external factors. The most signifiant problem is that by being fed from state financial resources, the universities are dependent on the social, economic, and political changes and these I turn have an impact on the education of engineers. Engineers, regardless of their abilities, skills, and attitudes, have a limited job market. Therefore, curriculum reform, continuous evaluation of the needs of the labour market by the university, training of skills appropriate to the fourth generation of industry and appointing professors who include academic development and modern skills in their programs, will not be very successful without intelligent interaction between the universities and society. Influenced by national and international factors, the employment market is not looking for the needs of its human resources among the qualified graduates of universities. The industries that reluctantly accept students to take practical courses, the false social demand for higher education, the inappropriate policy of higher education for the quantitative expansion of universities, the spread of the culture of credentialing, and other related issues have a significant influence on students' employability. Therefore, it can be said that the employability of engineering graduates is influenced by factors external to the universities, and the solution of this persistent problem can be found partly in improving the social basis for education and redefining the university- society connection.

\section{References}

Aghapour, S., Movahed M, S., \& Alambeigi, A. (2014). Key skills role in employability formation of college students. Quarterly Journal of Research and Planning in Higher Education, 20(1), 41-56.

Amiron, E., Abdul Latib, A., \& Subari, K. (2019). Industry revolution 4.0 skills and enablers in technical and vocational education and training curriculum. International Journal of Recent Technology and Engineering (IJRTE), 8(1), 485-490.

Azizi, M., \& Shafiezadeh, E. (2013). Entrepreneurial University: Necessity, features, and requirements. Tehran: Research Center of the Islamic Consultative Parlement. https://rc.majlis.ir/fa/mrc report/show/863422

Azmi, A., Kamin, Y., \& Noordin, M. (2018). Towards industrial revolution 4.0: Employers' expectations on fresh engineering graduates. International Journal of Engineering \& Technology, 7(28), 267-272. DOI:10.14419/ijet.v7i4.28.22593

Bagherinejad, J. (2010). A systematic approach to quality in higher education within the framework of the national innovation system. Industry and university, 3(7/8), 13-23. https://www.sid.ir/Fa/Journal/ViewPaper.aspx?ID=152434

Barabadi, A., Mohammadi, m., \& Asadi, A. (2009). Educational, social and cultural barriers to the employment of agricultural graduates. Economics, labor, and society, No.109,92-100. http://ensani.ir/file/download/article/20120327183519-3065-315.pdf

Bazargan, A. (2018). An introduction to qualitative \& mixed methods. Tehran, Iran: Didar.

Bridgstock, R. (2009). The graduate attributes we've overlooked: Enhancing graduate employability through career management skills. Higher Education Research And Development, 28(1), 31-44.

Brooks, R., \& Youngson, P. (2016). Undergraduate work placements: An analysis of the effects on career progression. Studies in Higher Education, 41(9), 1563-1578.

Clark, B. (2001). The entrepreneurial university: New foundations for collegiality, autonomy, and achievement. Higher Education Management, 13(2), 9-24.

de Grip, A., van Loo, J., \& Sanders, J. (2004). The Industry Employability Index: Taking account of supply and demand characteristics. International Labour Review, 143(3), 211-233. Retrieved from International Labour Organisation 2004.

Enayati Novinfar, A., Darani, K., \& Karamdoust, N. A. (2013). a comparative evaluation of effective factors in students' major selection at educational sciences and engineering colleges in University of Tehran,

Farhadi Rad, H., Parsa, A., \& Rajabi, E. (2020). Employability of Iranian Engineering graduates: Influential factors, consequences and 
Quarterly Journal of Research and Planning in Higher Education, 18(4), 145-167

http://journal.irphe.ac.ir/article-1-1763-en.html

Emadzadeh, M. (2015). Economics of education. Isfahan: Jahad Daneshgahi.

Entezari, Y. (2016). Higher education and graduates employment capabilities. Iranian Journal of Higher Education of Iran, 8(3), 1-25.

Ezati, M., \& Salmani, Y. (2015). Investigating the direct and indirect effects of sanctions on Iran's economic growth. Scientific Journal of Security Horizons, 7(25), 149-175.

https://www.sid.ir/fa/journal/ViewPaper.aspx?id=295233

Farhadi Rad, H., Mehralizadeh, Y., \& Hassanvand, S. (2017). Investigating the pattern of social demand for higher education in the five departments of Shahid Chamran University. Unpublished master thesis. Iran: Shahid Chamran University of Ahva.

Feyz, M. (2010). Identifying the desired professional qualifications of engineering graduates in Iran: Sharif University of Technology graduates. Unpublished master thesis. Iran: Shahid Beheshti University. http://library.sbu.ac.ir/islandora/object/thesis\%3A27567

Forrier, A., \& Sels, L. (2003). The concept employability: A complex mosaic. International Journal of Human Resources Development and Management, 3(2), 102-124. DOI:DOI: 10.1504/IJHRDM.2003.002414

Ferasatkhah, M. (2017). University history in Iran. Institute for Social and Cultural Studies, Ministry of Science, Research and Technology. Tehran, Iran

Gharba, M., Rahimi, H., \& Dehbashi, A. (2018). Educational gap: The break between the intended and learned curriculum in Iran's higher education system, Journal of Higher Education Curriculum Studies, 9(17), 93114. http://www.icsajournal.ir/article 66948 ab95a489423a8f491563c67ad1a20362.pdf

Gabureanu, S., \& Serbanescu, L. (2017). Enhancing employability of graduates in engineering. Edu World 2016 7th International Conference. Retrieved from file:///C:/Users/md/Desktop/Enhancing_Employability _of_Graduates_in_Engineerin.pdf

Gholami, Z., Arasteh, H., Navehebrahim, A., \& Zeinabadi, H. (2018). Designing a model of university research function With an industrial Assistant approach. Quarterly Journal of Strategic public policymaking, 8(28), 231-253.

Gribble, C. (2014). Exploring 'employability' in different cultural contexts. Melbourne: Society for Research in Higher Education. Retrieved from file:///C:/Users/md/Desktop/gribble-cate.pdf

Harvey, L. (2001). Defining and measuring employability. Quality in Higher Education, 7(2), 97-109.

Harun, H., Rohani, S., Rosli Baharom, M., \& Memon, M. (2017). Employability skills and attributes of engineering and technology graduates from employers' perspective: Important vs. satisfaction. Global Business and Management Research: An International Journal, 9(15), 573-581.

Hillage, J., \& Pollard, E. (1998). Employability: Developing a framework for policy analysis. London: Department for Education and Employment (DfEE). Research Brief No.85, available at:www.dfes.gov.uk/research/data/uplodfiles/RB85.doc.

Johnson, B., \& Christensen, L. (2016). Educational research: Quantitative, qualitative, and mixed approaches. SAGE Publications.

Khadem Alizadeh, A., Amadeh, H., \& Baghalian, M. (2014). The impact of economic sanctions on employment in Iran. Economic Strategy, 11(3), 79-104. https://civilica.com/doc/309526/

Khoshnevisan, F., Nasr, A., Neyestani, M., \& Sharif, M. (2016). A study of the educational needs of humanities postgraduate students in scope of labour market employability competencies with entrepreneurship approach: Findings of a mixed methods study. Journal of Career and Organisational Counseling, 8(26), 68-84.

Lindsay, C. (2009). The concept of employability and experience. Edinburgh: Napier University.

Lock, E., \& Kelly, K. (2020). Ignorance is risk: An exploratory investigation of students' perceptions of their education-employment pathways. Journal of Teaching and Learning for Graduate Employability, 11(1), 22-36.

Memarian, H. (2011). Deficiencies of Iran's engineering education programs. Iranian Journal of Engineering Education, 13(51), 53-74.

Mirkamali, M., \& Farhadi Rad, H. (2013). Research on the organisational structures of the university to provide an integrated model. educational management, 5(1),75-100. https://jearq.riau.ac.ir/article 552.html

Mohseni-Cheraghlou, A. (92017). Update from Iran: Iran's over-education crisis. World Bank Blogs. Accessed at https://blogs.worldbank.org/arabvoices/iran-education-crises

Motabari, M. (1999). Analytical study of factors affecting the choice of students major in some Iranian universities. Unpublished master thesis. Tehran: Tehran University.

Farhadi Rad, H., Parsa, A., \& Rajabi, E. (2020). Employability of Iranian Engineering graduates: Influential factors, consequences and strategies Journal of Teaching and Learning for Graduate Employability, 11(1), 110-130. 
Moghadas Noudeh, M. (2019). Investigating the challenges of university-industry cooperation: Great Tehran Electrical Distribution Company. Innovation Management, 8(1), 89-106.

http://www.nowavari.ir/article 91154.html

Mohammadpour, A. (2011). Qualitative research method counter method 1: The logic and design in qualitative methododology. Tehran: Jameeshenasan Publication.

Momeni Mahmoei, H., Shariatmadari, A., \& Naderi, E. (2008). The competency-based curriculum in higher education. Quarterly Journal of Educational Researches, 5(17),129-156. http://edu.bojnourdiau.ac.ir/article 518251 2bba9b5c744724b3e89b1d9bfa5e7929.pdf

Nguyen, D., Yanagawa, Y., \& Miyazaki, S. (2005). University education and employment in Japan. Students' perceptions on employment attributes and implications for university education. Quality Assurance in Education, 13, 202-218. Doi: 10.1108/09684880510607945

Nilsson, S. (2010). Enhancing individual employability: The perspective of engineering graduates. Education and Training, 52(6/7), 540-551. DOI:10.1108/00400911011068487

Nozari, H., \& Karimi, A. (2017). The role of formal and informal relations (social relations network) in the employment of students of Kharazmi University. Social Welfare, 17(64),161-198.

OEDC. (2018). The Organisation for Economic Co-operation and Development (OECD). Retrieved from OECD.Org: https://data.oecd.org/unemp/unemployment-rate.htm

Parand, K., Niroumand, P., Farajiarmaki, A., Alizadeh, A., \& Ahadieh, N. (2011). Provide a proposed framework for training and empowering students with a decent approach. Iranian First International Conference on Technology and Exports.

https://search.ricest.ac.ir/dl/search/searchPadTA.aspx?q=(f:0,t:\u0033\u0038\u0037\u0037\u0035,c:5)

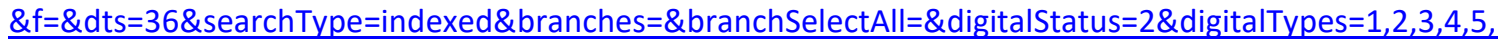
6,7\&sortfield=0\&sorttype=ASC\&RowPerPage $=10$ \&header $=$ false

Rahdari, M., Nasr, A., Nili, M., \& Turkladani, B. (2015). Assess the professional skills and employment status of undergraduate engineers. Research and Planning in Higher Education, 21(2),1-24. http://journal.irphe.ac.ir/article-1-2627-fa.html

Rahmani, R., \& Nazari Tavakoli, A. (2003). The challenges of the higher education system concerning the employment of graduates. The First Conference on Employment and the Country's Higher Education System. Tehran: Tarbiat-e-Modares University. https://civilica.com/doc/30140/

Renjen, P., \& Brown, S. (2018). Preparing tomorrow's workforce for the Fourth Industrial Revolution / For business: A framework for action. Deloitte Global and the Global Business Coalition. Accessed at: https://www2.deloitte.com/content/dam/Deloitte/global/Documents/About-Deloitte/gx-preparingtomorrow-workforce-for-4IR.pdf

Sando, A. (2018). Constructionist grounded theory - GT. Conceptual and methodological clarifications. Revista Romaneasca pentru Educatie Multidimensional, 10(1), 183-209. doi:doi.org/10.18662/rrem/28

Sharifi, A. M. F., Khorasani, A., Fathi V, K., \& Salehi Omran, I. (2017). Explaining the theoretical foundations of employability development of university graduates. Third International Conference on Management, Accounting, and Knowledge-Based Economics with an Emphasis on Resistance Economics. https://elmnet.ir/article/20725167-41312/

Sohrabi, F., Ebrahimi, S., \& Joukar, A. (2016). Scientific communication among university, industry \& government in Iran. Quarterly Journal of Research and Planning in Higher Education, 23(3), 21-41. http://journal.irphe.ac.ir/article-1-3444-fa.html

Statistical Center of Iran. (2018). Retrieved from Statistics Center of Iran: https://www.amar.org.ir/english

Strauss, A. L., \& Corbin, J. (1998), Basics of qualitative research: Techniques and procedures for developing grounded theory, 2nd Ed. USA: Sage.

Yaghoubi, M., \& Motahharenejad, H. (2011). Requirements for codifying strategies of engineering education in Iran. Iranian of Engineering Education, 13(51), 31-51.

Farhadi Rad, H., Parsa, A., \& Rajabi, E. (2020). Employability of Iranian Engineering graduates: Influential factors, consequences and strategies Journal of Teaching and Learning for Graduate Employability, 11(1), 110-130. 